\title{
EVALUATION OF GLYCOPROTEIN B GENOTYPES AND LOAD OF CMV INFECTING BLOOD LEUKOCYTES ON PROGNOSIS OF AIDS PATIENTS
}

Aldo Albuquerque CUNHA(1), Vitor Hugo AQUINO(1), Viviane MARIGUELA(1), Maurício Lacerda NOGUEIRA(2)\& Luiz Tadeu Moraes FIGUEIREDO(1)

\begin{abstract}
SUMMARY
Background: Cytomegalovirus (CMV) remains an important pathogen to immunocompromised patients even in the era of HAART. The present study aimed at evaluating the influence of CMV viral load and its gB genotypes on AIDS patients' outcome. Methods: Blood samples of 101 AIDS patients were collected and tested for HIV load, CD4 - cell count and opportunistic pathogens, including CMV. Seminested PCRs were run to detect CMV genome and in the positive samples, gB genotyping and CMV load were established using enzymatic restriction and real time PCR, respectively. All patients were clinically followed for four years. Results: In thirty patients $(31 \%)$ CMV was detected and all fatal cases $(n=5)$ occurred in this group of patients $(\mathrm{p}=0.007)$, but only two patients had CMV disease (1.9\%). However, viral load was not statistically associated with any analyzed parameter. The most frequently observed CMV genotype was gB2 (45.16\%) followed by gB3 (35.48\%). gB2 genotype was more frequently found in patients with CD4-cell counts under 200 cells $/ \mathrm{mm}^{3}(\mathrm{p}=0.0017)$, and almost all fatal cases $(80 \%)$ had $\mathrm{gB} 2$ genotype. Conclusions: Our study suggests that CMV and its polymorphisms in biologically relevant genes, such as the gB encoding ORF, may still influence the prognosis and outcome of AIDS patients. The gB2 genotype was associated to patient's bad outcome.
\end{abstract}

KEY WORDS: CMV, CMV load, HIV, AIDS, CMV genotypes.

\section{INTRODUCTION}

Cytomegalovirus (CMV) is a ubiquitous herpesvirus that is the causative of asymptomatic or mild symptomatic infections in immunocompetent hosts ${ }^{25}$. Conversely, in immunocompromised patients, such as those with AIDS or in transplant recipients, CMV might produce significant morbidity and mortality ${ }^{2,17}$.

CMV glycoprotein $\mathrm{B}(\mathrm{gB})$ is a highly immunogenic protein incorporated into the viral envelope, which is believed to exert an essential biological role in virus host interaction, since it participates in the entry, propagation and replication of the virus in different host cells $^{3,18}$. Wild type CMV strains can be classified into four major $\mathrm{gB}$ genotypic variants ( $\mathrm{gB} 1-4)$ based on $\mathrm{gB}$ sequence. Each of them have tropism for distinct cell lines, leading to different pathogenesis and severity of disease ${ }^{6,20,23,27}$. Thus, the genotypic characterization of CMV strains infecting immunocompromised individuals can contribute to epidemiological molecular studies and to the definition of the role of viral genetic variability in clinical expression and prognosis. Besides this, CMV infection might reduce patient's immune response, favoring the onset of opportunistic diseases and in some cases, death ${ }^{24}$.

Several studies have tried to correlate the infection by different $\mathrm{gB}$ genotypes of CMV with clinical prognosis of individuals ${ }^{4,5,27,28}$. Therefore, the aims of the present study were to determine the incidence of CMV infecting blood leukocytes of HIV-infected individuals in a Brazilian care unit, the incidence of $\mathrm{gB}$ genotypes and loads of their infective CMV strains, and correlate this information with laboratorial and clinical data obtained during a 4-year follow-up.

\section{PATIENTS AND METHODS}

One hundred one AIDS patients at different phases of the disease and followed at the General Hospital of the School of Medicine of Ribeirão Preto/University of São Paulo (HCFMRP/USP) and at the county ambulatories of Jaboticabal and Monte Alto (São Paulo State, Brazil), were invited to participate in this study. This protocol was approved by the Ethics Review Board of HCFMRP-USP (process \# 1976/2002).

Blood samples were collected from 2001 to 2002 and all participants attended follow-up visits every three months during four years. The following clinical data were registered during their visits: gender, age, stage of HIV infection, occurrence of opportunistic infections including those caused by CMV, and information on the intake of highly active antiretroviral therapy (HAART). T-CD 4 cell counts and HIV loads by

The authors state that this work has never been presented in any scientific meeting and these data has never been published elsewhere.

(1) Virology Research Unit, School of Medicine of Ribeirão Preto, University of São Paulo, Ribeirão Preto, SP, Brazil..

(2) Laboratory of Virology, Faculdade de Medicina de São José do Rio Preto, FAMERP, São José do Rio Preto, SP, Brazil

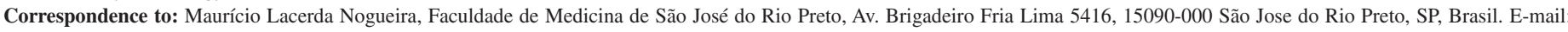
Mauricio.nogueira@pq.cnpq.br 
CUNHA, A.A.; AQUINO, V.H.; MARIGUELA, V.; NOGUEIRA, M.L. \& FIGUEIREDO, L.T.M. - Evaluation of glycoprotein B genotypes and load of CMV infecting blood leukocytes on prognosis of AIDS patients. Rev. Inst. Med. Trop. Sao Paulo, 53(2): 83-8, 2011.

the time of first sampling and in the last clinical visit were included in the study as laboratorial parameters of patient development.

DNA extraction and nested-PCR for detection of CMV genome: For PCR test, the blood samples $(5 \mathrm{~mL})$, collected in EDTA-containing tubes, leukocytes were separated with the addition of $1 \%$ dextran solution and the DNA of the cells from the buffy coat were extracted by the phenol-chlorophorm method ${ }^{16}$. To amplify CMV DNA we used a nested-PCR technique previously reported by CUNHA et al. ${ }^{7}$. The PCR was performed using CMV primers as follows: gB 1319 (5'-TGGAACTGGAACGTTTGGC3') and gB 1604 (5'GAAACGCGCGGCAATCGG-3') as external primers. In the second round a nested PCR was performed using gB 1319 (5'-TGGAACTGGAACGTTTGGC3') and gB 1676 (5'TGACGCTGGTTTGGTTGAATG3') as external primer. The reaction mixture of the PCR contained in a total volume of $50 \mu \mathrm{L}, 75 \mathrm{mM}$ of Tris $\mathrm{HCl}$ (pH 9), $2 \mathrm{mM}$ of $\mathrm{MgCl}_{2}, 50 \mathrm{mM}$ of $\mathrm{KCl}, 20 \mathrm{mM}$ of $\left(\mathrm{NH}_{4}\right)_{2} \mathrm{SO}_{4}, 50 \mu \mathrm{M}$ of each one of the deoxynucleoside triphosphates, $0.3 \mu \mathrm{M}$ of primers gB1319 and gB1604, and one $\mu \mathrm{g}$ of DNA obtained from primary blood lymphocytes. The reaction mixture was first incubated at $94^{\circ} \mathrm{C}$ for three min. Next, the temperature was reduced to $80^{\circ} \mathrm{C}$, when $2 \mathrm{U}$ of Taq DNA polymerase were added and the mixture was submitted to 15 cycles of $60 \mathrm{sec}$ at $94{ }^{\circ} \mathrm{C}, 120 \mathrm{sec}$ at $65^{\circ} \mathrm{C}$, and $120 \mathrm{sec}$ at $72{ }^{\circ} \mathrm{C}$, and to 30 cycles of $60 \mathrm{sec}$ at $94{ }^{\circ} \mathrm{C}, 90 \mathrm{sec}$ at $55^{\circ} \mathrm{C}, 120 \mathrm{sec}$ at $72{ }^{\circ} \mathrm{C}$, and finally to three min at $72{ }^{\circ} \mathrm{C}$. Two microliters of these reaction products were used in the nested-PCR, included in a reaction mixture similar to that mentioned above, except for the primers gB1319 and gB1604. PCR and nested-PCR products were subjected to electrophoresis in a $2 \%$ agarose gel and the amplicon bands were visualized under UV light after ethidium bromide staining. A 100 base pair (bp) marker (Amersham Pharmacia, USA) was used to estimate the size of bands. Amplicons from nested-PCR were further used for genotyping CMV.

CMV load by real time PCR: In DNA extracts of leukocytes in which CMV was detected by nested-PCR, the CMV load was also determined by real time PCR. The reaction was carried out using a 40-cycle TaqMan PCR assay. The reaction mixture, containing primers and probe designed in our laboratory from the region of $\mathrm{gB}-\mathrm{CMV}$, included 10 picomols/10 $\eta \mathrm{l}$ of the forward primer (5'-TGGAATCGGTGCACAATCTG-3') and 10 picomols/10 $\eta 1$ of the reverse primer (5'-CGCGCAACGTGTCATAGG-3') in a volume of $1 \mu \mathrm{L}$, five picomols/10 $\eta 1$ of a probe (6FAMACGCCCAGCTGCAGTT MGBNFQ) in a volume of one $\mu \mathrm{L}$, master-mix ( $2 \mathrm{x}$ concentrated) buffer containing TaqMan in a volume of five $\mu \mathrm{L}$, plasmid or clinical sample DNAs in a volume of one $\mu \mathrm{L}$ of DEPC treated water, in a final volume of $10 \mu \mathrm{L}$. The reaction was carried out in a RT-PCR 7500 device (Applied Biosystems, USA), and was monitored from 700 to $770 \mathrm{~nm}$. To avoid false positive results, specimens were processed in parallel with negativecontrol aliquots of phosphate buffered saline. PCR were run in triplicate and the final CMV load was considered as the mean of the three values.

CMV genotyping: The amplicons of CMV obtained by nestedPCR were submitted to an enzymatic cleavage for gB genotyping. In this case, $10 \mu \mathrm{L}$ of a mixture containing the amplicons were added to a microtube containing two uL of the proper buffer solution. The enzymes HinfI or RsaI (New England Biolabs, USA) (10 U, from each enzyme) were added to the solution, the volume being $20 \mu \mathrm{L}$. After one hour incubation at $37{ }^{\circ} \mathrm{C}$, the digested products were visualized in a $1 \%$ agar gel, after electrophoresis at $100 \mathrm{~V}$, for $45 \mathrm{~min}$. This procedure allowed discrimination of fragments with similar weights (up to $10 \mathrm{bp}$ ), and thus the identification of the four described gB genotypes ${ }^{6}$.

Statistical analysis: The model of logistic regression was used to verify the influence of CMV viral load over T-CD4 counts, HIV viral load, medication intake and incidence of death and opportunistic infections. The unpaired Student's t-test was used for analysis of parametric data, such as time of diagnosis and age from CMVpositive and negative individuals.

To analyze differences in CMV viral loads and T-CD4 counts among groups of samples with different CMV genotypes, Kruskal-Wallis nonparametric test was used and in case of significance, the post-test of multiple comparisons ${ }^{10}$ was performed.

\section{RESULTS}

CMV detection by semi-nested-PCR: Analyzing leukocyte samples from 101 AIDS patients CMV genome was detected in 31 (31\%). In these patients, CMV was detected at different times during follow-up. Baseline information on patients with positive and negative samples for CMV is shown in Table 1. In the group of patients with CMV positive samples, 30 to 35 year-old females predominated, while in the CMV

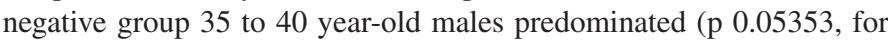
gender and $\mathrm{p} 0.6$, for age). The time since AIDS was diagnosed did not differ for both groups ( $\mathrm{p} 0.141$ ).

Table 1

Characteristics of patients with detected CMV genome and patients with negative blood samples

\begin{tabular}{|c|c|c|}
\hline & $\begin{array}{l}\text { CMV negative } \\
\mathrm{n}=70\end{array}$ & $\begin{array}{l}\text { CMV positive } \\
\mathrm{n}=31\end{array}$ \\
\hline \multicolumn{3}{|l|}{ Gender } \\
\hline Male & $60 \%$ & $33 \%$ \\
\hline Female & $40 \%$ & $67 \%$ \\
\hline Age (Mean \pm SE) & $37.64 \pm 1.190$ & $38.77 \pm 1.797 ; p=0.60$ \\
\hline \multicolumn{3}{|l|}{ Current HIV treatment } \\
\hline None $^{1}$ & $20 \%$ & $23 \%$ \\
\hline $3 \mathrm{ARVs}$ & $60 \%$ & $71 \%$ \\
\hline Booster & $20 \%$ & $6 \%$ \\
\hline \multicolumn{3}{|l|}{ Use of ARVs ${ }^{2}$} \\
\hline Regular use & $44 \%$ & $46 \%$ \\
\hline Irregular use & $56 \%$ & $54 \%$ \\
\hline $\begin{array}{l}\text { T-CD4 counts, cells } / \mathrm{mL} \\
(\text { Mean } \pm \mathrm{SE})\end{array}$ & $426.1 \pm 32.49$ & $290.6 \pm 47.15^{*} ; p=0.02$ \\
\hline $\begin{array}{l}\text { Time (yrs) since HIV } \\
\text { diagnosis }(\text { Mean } \pm \text { SE) }\end{array}$ & $5.66 \pm 1.93$ & $5.00 \pm 1.77 ; p=0.141$ \\
\hline
\end{tabular}

${ }^{1}$ Patients in this group either abandoned medication, had it suspended for any reason or did not start the medication. ${ }^{2}$ Data from this item correspond to what is declared by patients. *Data compared using non-paired t-test, $95 \%$ confidence interval. 
At the end of the follow-up, most of the patients with detected CMV were also symptomatic for HIV-related infections (53\%). Among then, toxoplasmosis was the opportunistic infection most frequently detected (12\%). The group of participants without CMV infection of leukocytes was mostly asymptomatic (70\%) and tuberculosis was the most frequent opportunistic infection (14\%). Moreover, in the majority of patients at C3 AIDS stage CMV was detected in leukocytes (p 0.0064) (Table 2). Also, five of the patients died during this period (Table 3 ).

During follow-up the CD4-cell counts increased in values for the majority of the enrolled patients, and the HIV loads remained stable throughout the study period; in spite of most participants making irregular use of HAART.

Regarding CMV disease, only two patients in the CMV positive group had diagnosis of encephalitis and esophagitis (6\%, p 0.1005, OR 0.08936 ) by this virus. However, $16 \%$ of the patients with CMV detected in the leukocytes died during the follow-up while no deaths occurred among those uninfected by CMV (p 0.0021).

Table 2

Characteristics of enrolled patients at the end of the study

\begin{tabular}{lcc}
\hline & $\begin{array}{c}\text { CMV negative } \\
\mathrm{n}=70\end{array}$ & $\begin{array}{c}\text { CMV positive } \\
\mathrm{n}=31\end{array}$ \\
\hline Asymptomatic & $70 \%$ & $47 \%$ \\
Opportunistic infections & $10 \%$ & $12 \%$ \\
Toxoplasmosis & $14 \%$ & $9 \%$ \\
Tuberculosis & $0 \%$ & $6 \%$ \\
Cryptococcus & $0 \%$ & $6 \%$ \\
Pneumocystosis & $0 \%$ & $3 \%$ \\
CMV Encephalitis & $10 \%$ & $9 \%$ \\
Other opportunist infection & $0 \%$ & $12 \%$ \\
Deaths & & \\
\hline
\end{tabular}

CMV viral load: The real time PCR was able to detect one copy of the plasmid containing part of the gB gene of CMV. Therefore, CMV load of the participants ranged from 100 to 35,000 viral copies $/ 1.5 \times 10^{5}$ leukocytes. Considering as high CMV load values above 200 viral copies $/ 1.5 \times 10^{5}$ leukocytes, two groups of CMV-AIDS patients were created, including those with $<200$ and $>200 \mathrm{CMV}$ copies $/ 1.5 \times 10^{5}$ leukocytes. No association was observed for the values of CMV and HIV viral loads ( $p$ $=0.6144$ ) and neither for CMV loads and T-CD4 cell counts ( $\mathrm{p} 0.3947)$ (Table 4). However, three out five fatal cases had $>200$ viral copies of CMV/1.5 x $10^{5}$ leukocytes and also T-CD4 cell counts under 55 cells $/ \mathrm{mL}$.

A number higher than 200 viral copies of CMV/1.5 x $10^{5}$ leukocytes had $60 \%$ sensitivity, $34 \%$ specificity, $15 \%$ predictive positive value and $82 \%$ predictive negative value for prediction of bad prognosis of AIDS.

gB genotypes of CMV: All $4 \mathrm{gB}$ genotypes of CMV were observed in the leukocytes of the AIDS patients and frequency distribution of genotypes was $45.16 \%$, in $35.48 \%, 12.9 \%$ and $6 \%$ for gB2, gB3, gB4 and $\mathrm{gB} 1$, respectively.

Table 5 shows median values of CD4-cell counts and CMV viral loads among samples having different $\mathrm{gB}$ genotypes. Although most individuals infected with gB2 genotype had CMV loads higher than 200 viral copies $/ 1.5 \times 10^{5}$ leukocytes, no statistical difference was observed for mean CMV loads (p 0.11). However, most patients infected with gB2 strain had T-CD4 counts below 200 cells/mL (p 0.0017). Also, gB2 genotype was present in leukocytes of $80 \%$ (4/5) of the fatal cases. Conversely, the frequency of gB3 genotype was higher among individuals with CMV loads $<200$ viral copies $/ 1.5 \times 10^{5}$ leukocytes.

The presence of gB2 genotype of CMV infecting leukocytes as a predictor of bad prognosis for AIDS showed $80 \%$ sensitivity, $61.5 \%$ specificity, $28 \%$ positive predictive value and $94 \%$ negative predictive value.

\section{DISCUSSION}

This 4-year follow-up work focused on the effects of CMV infection in AIDS patients, analyzing the association of CMV load and $\mathrm{gB}$

Table 3

Key findings from patients that came to death during the follow-up

\begin{tabular}{|c|c|c|c|c|c|}
\hline & Patient 1 & Patient 2 & Patient 3 & Patient 4 & Patient 5 \\
\hline CD4-cell count & 38 & 35 & 53 & 41 & 6 \\
\hline CMV viral load & 117 & 16900 & 758 & 120 & 707 \\
\hline HIV viral load & 67170 & 230000 & 256247 & 71556 & 16761 \\
\hline CMV genotype & gB3 & $\mathrm{gB} 2$ & $\mathrm{gB} 2$ & $\mathrm{gB} 2$ & $\mathrm{gB} 2$ \\
\hline Opportunistic infection & & Neurocripto & Pneumocystosis & Cryptococcosis & Neurotoxoplasmosis \\
\hline Years from AIDS diagnosis & 3 & 5 & 2 & $>5$ & 3 \\
\hline Medication intake & NA & Irregular & Irregular & Irregular & Regular \\
\hline HAART regimen & NA & Biovir+EFV & Biovir+EFV & Biovir+EFV & Biovir+EFV \\
\hline
\end{tabular}

NA - Not applicable. 
CUNHA, A.A.; AQUINO, V.H.; MARIGUELA, V.; NOGUEIRA, M.L. \& FIGUEIREDO, L.T.M. - Evaluation of glycoprotein B genotypes and load of CMV infecting blood leukocytes on prognosis of AIDS patients. Rev. Inst. Med. Trop. Sao Paulo, 53(2): 83-8, 2011.

Table 4

Frequencies of individuals in two ranges of values for CMV viral loads and different T-CD4 cell counts

\begin{tabular}{lccc}
\hline & \multicolumn{2}{c}{ CMV load } & $\begin{array}{c}\text { p-value } \\
\text { Odds Ratio }\end{array}$ \\
\cline { 2 - 3 } & $<200$ & $>200$ & \\
\hline T-CD4 cell counts & & 11 & $1.173(0.477 ; 2.880)$ \\
\hline $0-200$ & 4 & 6 & \\
$200-500$ & 3 & 6 & $0.3947^{\mathrm{b}}$ \\
$>500$ & 1 & & $1.732(0.489 ; 6.137)$ \\
\hline HIV viral load & & & 0.6144 \\
$<10000$ copies & 3 & 5 & $1.528(0.294 ; 7.944)$ \\
$>10000$ copies & 11 & 12 &
\end{tabular}

Data in this table is represented by number of patients. Statistical analysis used logistic regression model with $95 \%$ confidence interval. (a) p-values and odds ratio for the influence of CMV loads on T-CD4 counts from 0-200 and 200-500. (b) p-values and odds ratio for the influence of CMV loads on T-CD4 counts from 200-500 and $>500$.

Table 5

Values of CD4-cell counts and CMV viral loads in samples of patients with different $\mathrm{gB}$ genotypes

\begin{tabular}{lcccc}
\hline Genotype & Variable & Median & Min value & Max value \\
\hline gB1 & CD4 & 487 & 449 & 525 \\
& CMV & 1615 & 660 & 2570 \\
gB2 & CD4 & 99.5 & 6 & 334 \\
& CMV & $1560 * *$ & 120 & 32300 \\
gB3 & CD4 & 341 & 38 & 1149 \\
& CMV & 125 & 100 & 3380 \\
gB4 & CD4 & 510 & 492 & 548 \\
& CMV & 289 & 100 & 2400 \\
\hline
\end{tabular}

Data from 31 patients with CMV detected genome by PCR. Analyses were performed using Kruskal-Wallis test for CD4-cell counts (cell $/ \mathrm{mm}^{3}$ ) and viral loads (viral copies $/ 1.5 \times 10^{5}$ leukocytes). Dunn's test was used as post test. $* * \mathrm{p}<0.001$.

genotypes as parameters of disease development and prognosis. This information was obtained by molecular biology techniques such as PCR, which are widely considered as suitable tools. The drawback of this technique is the high sensitivity, which raised concern regarding the diagnosis of the pathogen effectively causative of patient's clinical symptoms. Previously, we have used PCR for CMV genome detection in samples of children and patients with kidney transplant, obtaining specific and reproducible results ${ }^{1,7,29}$, although with a highly sensitive method, we could be detecting latent CMV incorporated into leukocytes DNA ${ }^{19}$. Thus, to improve the diagnosis of CMV disease, a real time PCR virus quantification method was used trying to establish a clinically relevant cut-off value for CMV viral load in leukocytes.

Our data point to a high prevalence of CMV (31\%) among AIDS patients when compared to that observed by DEYTON et al. ${ }^{8}$. These authors looked for CMV genome by PCR in blood samples of a group of 374 patients during a follow-up study of 37 months. According to these authors, in the initial test, CMV genome was detected in $15.8 \%$ of samples (59 patients). Although the rate of positive samples was not stable throughout the above follow-up study, the difference in values of initially positive samples with the present study could be explained by the high prevalence of CMV infection in Brazil, about 95\% $\%^{7,29}$.

Considering the baseline population characteristics, our results are similar to those reported by a multicentre study conducted by JABS et $a l .{ }^{15}$, except for the high prevalence of females in the CMV detected group. Moreover, similar to our data, most patients in this previous report were using HAART. Interestingly, our results demonstrate that a large proportion of patients had referred to an irregular use of HAART during the follow-up period, although there was no increase of their HIV loads, indicating that even used irregularly, HAART may decrease HIV replication and thus allow the rescue of immune function.

The issue of whether CMV remains as a risk factor for patients receiving HAART has been reviewed elsewhere ${ }^{14,26}$. Both works came to the conclusion that HAART reduced the incidence of CMV disease among patients, although CMV remains a risk factor for prognosis of AIDS patients with CD4-cell counts below 100 cells $/ \mathrm{mm}^{3}$. Our results showed that the presence of CMV in blood leukocytes was associated with case fatality and in all death cases patients had CD4 below 55 cell $/ \mathrm{mm}^{3}$, indicating that they were severely immune depressed. Probably, as a consequence, these patients had high CMV loads, which could also contribute to disease progression. None of the fatal cases had symptoms of CMV disease, suggesting that CMV itself was not the direct cause of death of these patients. In this regard, SPENCER et al. ${ }^{24}$ suggested that CMV indirectly contributes to immune depression of AIDS patients. These authors related the presence of an interleukine-10-like protein that is expressed during CMV infection. This protein suppresses Th1 immune response, acting synergistically with HIV aggravating immune system depression.

Considering CMV loads, our real time PCR was highly sensitive being able to detect one copy of plasmid per $\mu \mathrm{L}$, similar to that reported by SANCHEZ \& STORCH ${ }^{22}$ using the same technique. Therefore, the values for CMV viral loads ranged from 100 to 35,000 viral copies/1.5x $10^{5}$ leukocytes with the majority of patients presenting $>200$ viral copies/1.5 x $10^{5}$ leukocytes. GOURLAIN et al. ${ }^{13}$ reported that six out of 16 patients with CMV loads higher than 100 viral copies/1.5 x $10^{5}$ leukocytes (detected by RT-PCR) developed CMV disease. Plasma samples from these patients had $\mathrm{CD} 4^{+}$- cell counts below 75 cells $/ \mathrm{mm}^{3}$ and HIV loads higher than 100,000 viral copies/mL which was also predictive of CMV disease. In our work, CMV viral loads were not correlated with CD4 counts, HIV loads or incidence of death, although high CMV viral loads were observed in one fatal case. Also, our data points to a low incidence of CMV disease, two out of 31 patients with CMV genome detected had CMV disease based on suggestive clinical presentation of CMV encephalitis and esophagitis. In both cases, viral loads were higher than 200 viral copies $/ 1.5$ x $10^{5}$ leukocytes.

Considerable attention has been paid to the glycoprotein B from CMV viral envelope and many studies have tried to establish the influence of different gB genotypes (gB1-4) on the patient's outcome [for review see 
CUNHA, A.A.; AQUINO, V.H.; MARIGUELA, V.; NOGUEIRA, M.L. \& FIGUEIREDO, L.T.M. - Evaluation of glycoprotein B genotypes and load of CMV infecting blood leukocytes on prognosis of AIDS patients. Rev. Inst. Med. Trop. Sao Paulo, 53(2): 83-8, 2011.

26]. However, the correlation of $g B$ genotypes and disease progression is still unclear. The distribution frequencies of $\mathrm{gB}$ genotypes may vary according to groups of immunocompromised patients. In bone marrow transplant recipients and AIDS patients, gB2 and 3 are more often found, while in congenitally infected babies $\mathrm{gB} 1$ is more frequent ${ }^{3}$. Our findings indicate that $\mathrm{gB} 2$ genotype was most encountered (45.16\%) in samples of AIDS patients with CD4-cell counts below $200 \mathrm{cells} / \mathrm{mm}^{3}$, although CMV disease was rarely observed. Also, patients with gB2 strains had CMV loads higher than 200 copies $/ 1.5 \times 10^{5}$ leukocytes, but again no association between genotype and viral load was observed. Besides, it was observed in another study that neutralizing an antibody to gB2 human cytomegalovirus does not prevent reactivation in patients with human immunodeficiency virus infection ${ }^{21}$.

Interestingly, in our work, 80\% (4/5) of patients that died were infected with gB2 CMV genotype, which could be due either to the high prevalence of this genotype or to a real association of $\mathrm{gB} 2$ and immune suppression. In a previous study, GILBERT et al. ${ }^{11}$ observed a similar predominance of gB2 genotype patients with low CD4-cell counts in AIDS patients with and without CMV retinitis, indicating no association between genotype and disease. DREW et al., in 2002, found that half of AIDS patients had gB2 genotype and that this genotype is not a major determinant of retinitis pathogenicity but appears to be highly prevalent among HIV-infected patients $^{9}$. In the Netherlands, differently, however, it was found that CMV gB3 was the most prevalent gB genotype in AIDS patients, but also double or triple infection with other CMV gB strains were common ${ }^{12}$. Nevertheless, the confirmation of the virulence of gB2 genotype observed in the present study must be assessed in a larger casuistic study.

\section{CONCLUSIONS}

Cytomegalovirus infection remains as a risk factor for immunocompromised individuals, even in the HAART era. Although the presence of CMV genome was not associated with the incidence of CMV disease, a relevant proportion of patients coinfected with HIV and CMV died (12\%), while CMV genome was detected mostly in individuals with CD4-cell counts lower than 100 cells $/ \mathrm{mm}^{3}$. Moreover, our results may raise the issue of whether the presence of CMV gB2 genotype could be a predictor of bad prognosis and decrease of immune response, even in patients using HAART. In the light of these facts, an integration of clinical and virological data may favor the evaluation of prognosis of AIDS patients.

\section{CONFLICTS OF INTEREST}

The authors declare no conflicts of interest whatsoever.

\section{RESUMO}

\section{Avaliação de genótipos de glicoproteína B e carga de CMV de leucócitos no prognóstico de pacientes de Aids}

Antecedentes: O citomegalovírus (CMV) permanece um importante patógeno para pacientes imunocomprometidos, mesmo na era da HAART. O presente estudo teve como objetivo avaliar a influência da carga viral do CMV e seu genótipo gB sobre a evolução de pacientes com AIDS. Métodos: Amostras de sangue de 101 pacientes com AIDS foram coletadas e testadas para carga viral de HIV, a contagem de células
CD4 e patógenos oportunistas, incluindo o CMV. Um sistema de PCRs seminested foi utilizado para detectar o genoma do CMV e em amostras positivas a carga viral de CMV e genotipagem foram estabelecidos por restrição enzimática e PCR em tempo real, respectivamente. Todos os pacientes foram acompanhados clinicamente durante quatro anos. Resultados: Trinta pacientes (31\%) tiveram CMV detectado e todos os casos fatais $(n=5)$ ocorreram em pacientes deste grupo $(\mathrm{p}=0,007)$, porém apenas dois pacientes tinham doença por CMV $(1,9 \%)$. No entanto, a carga viral não foi associada estatisticamente a nenhum dos parâmetros analisados. O genótipo de CMV mais freqüentemente observado foi gB2 $(45,16 \%)$, seguido por gB3 $(35,48 \%)$. O genótipo gB2 foi mais freqüente em pacientes com contagens abaixo de 200 células $/ \mathrm{mm}^{3} \mathrm{CD} 4$ cell ( $\mathrm{p}=$ 0,0017), e quase todos os casos fatais $(80 \%)$ tinham o genótipo gB2. Conclusão: Nosso estudo sugere que CMV e seu polimorfismo em genes relevantes biologicamentes, como a gB, pode ainda influenciar no prognóstico e evolução de pacientes com AIDS. O genótipo gB2 foi associado ao mau prognóstico do paciente.

\section{ACKNOWLEDGEMENTS}

This work was supported by São Paulo State Research Foundation (FAPESP), process number 02/019603. MLN and LTMF are recipients of CNPq Fellowships.

The authors are grateful to Ms Soraya Jabur Badra and Mr. Haroldo Alves Ferreira Junior for technical assistance and Mr. Abílio Borghi for critical reading of the manuscript.

\section{REFERENCES}

1. Aquino VH, Figueiredo LTM. High prevalence of renal transplant recipients infected with more than one cytomegalovirus glycoprotein B genotype. J Med Virol. 2000;61:138-42.

2. Arens M. Clinically relevant sequence-based genotyping of $\mathrm{HBV}, \mathrm{HCV}, \mathrm{CMV}$, and HIV. J Clin Virol. 2001;22:11-29.

3. Arista S, De Grazia S, Giammanco GM, Di Carlo P, Iannitto E. Human cytomegalovirus glycoprotein B genotypes in immunocompetent, immunocompromised, and congenitally infected Italian populations. Arch Virol. 2003;148:547-54.

4. Bongarts A, Von Laer D, Vogelberg C, Ebert K, Van Lunzen J, Garweg J, et al. Glycoprotein B genotype of human cytomegalovirus: distribution in HIV-infected patients. Scand J Infect Dis. 1996;28:447-9.

5. Chern KC, Chandler DB, Martin DF, Kuppermann BD, Wolitz RA, Margolis TP Glycoprotein B subtyping of cytomegalovirus (CMV) in the vitreous of patients with AIDS and CMV retinitis. J Infect Dis. 1998;178:1149-53.

6. Chou SW, Dennison KM. Analysis of interstrain variation in cytomegalovirus glycoprotein B sequences enconding neutralization-related epitopes. J Infect Dis. 1991;163:1229-34.

7. Cunha AA, Marin LJ, Aquino VH, Figueiredo LTM. Diagnosis of cytomegalovirus infections by qualitative and quantitative PCR in HIV infected patients. Rev Inst Med Trop Sao Paulo. 2002;44:127-32.

8. Deayton JR, Wilson P, Sabin CA, Davey CC, Johnson MA, Emery VC, et al. Changes in the natural history of cytomegalovirus retinitis following the introduction of highly active antiretroviral therapy. AIDS. 2000;14:1163-70.

9. Drew WL, Chou S, Miner RC, Mohr BA, Busch MP, van der Horst CM, et al Cytomegalovirus glycoprotein B groups in human immunodeficiency virus-infected patients with incident retinitis. J Infect Dis. 2002;186:114-7. 
CUNHA, A.A.; AQUINO, V.H.; MARIGUELA, V.; NOGUEIRA, M.L. \& FIGUEIREDO, L.T.M. - Evaluation of glycoprotein B genotypes and load of CMV infecting blood leukocytes on prognosis of AIDS patients. Rev. Inst. Med. Trop. Sao Paulo, 53(2): 83-8, 2011.

10. Dunn OJ. Multiple comparisons using rank sums. Technometrics. 1964;6:241-52.

11. Gilbert C, Handfield J, Toma E, Lalonde R, Bergeron MG, Boivin G. Human cytomegalovirus glycoprotein B genotypes in blood of AIDS patients: lack of association with either the viral DNA load in leukocytes or presence of retinitis. J Med Virol. 1999;59:98-103.

12. Goossens VJ, Wolffs PF, van Loo IH, Bruggeman CA, Verbon A. CMV DNA levels and CMV gB subtypes in ART-naive HAART-treated patients: a 2-year follow-up study in The Netherlands. AIDS. 2009;23:1425-9.

13. Gourlain K, Salmon D, Gault E, Leport C, Katlama C, Matheron S, et al. Quantitation of cytomegalovirus (CMV) DNA by real-time PCR for occurrence of CMV disease in HIV-infected patients receiving highly active antiretroviral therapy. J Med Virol. 2003;69:401-7

14. Griffiths PD. CMV as a cofactor enhancing progression of AIDS. J Clin Virol. 2006;35:489-92.

15. Jabs DA, Holbrook JT, Van Natta ML, Clark R, Jacobson MA, Kempen JH, et al. Risk factors for mortality in patients with AIDS in the era of highly active antiretroviral therapy. Ophthalmology. 2005;112:771-9.

16. Maniatis T, Jeffrey A, Kleid DG. Nucleotide sequence of the rightward operator of phage lambda. Proc Natl Acad Sci USA. 1975;72:1184-8.

17. Michel D, Marre E, Hampl W, Roczkos J, Müller S, Hertenstein B, et al. Intestinal cytomegalovirus disease in immunocompromised patients may be ruled out by search for cytomegalovirus DNA in stool samples. J Clin Microbiol. 1995;33:3064-7.

18. Navarro D, Paz P, Tugizov S, Topp K, La Vail J, Pereira L. Glycoprotein B of human cytomegalovirus promotes virion penetration into cells, the transmission of infection from cell to cell, and fusion of infected cells. Virology. 1993;197:143-58.

19. Pellegrin I, Carrigue I, Binquet C, Chene G, Neau D, Bonot P, et al. Evaluation of new quantitative assays for diagnosis and monitoring of cytomegalovirus disease in human immunodeficiency virus-positive patients. J Clin Microbiol. 1999;37:3124-32.
20. Pignatelli S, Dal Monte P, Rossini G, Landini MP. Genetic polymorphisms among human cytomegalovirus (HCMV) wild-type strains. Rev Med Virol. 2004;14:383-410.

21. Rasmussen L, Cowan CM. Neutralizing antibody to gB2 human cytomegalovirus does not prevent reactivation in patients with human immunodeficiency virus infection. J Gen Virol. 2003;84:1853-7.

22. Sanchez JL, Storch GA. Multiplex, quantitative, realtime PCR assay for cytomegalovirus and human DNA. J Clin Microbiol. 2002,40:2381-6.

23. Shepp DH, Match ME, Ashraf AB, Lipson SM, Millan C, Pergolizzi R, et al Cytomegalovirus glycoprotein B groups associated with retinitis in AIDS. J Infect Dis. 1996; 174:184-7.

24. Spencer JV, Lockridge KM, Barry PA, Lin G, Tsang M, Penfold ME, Schall TJ. Potent immunosuppressive activities of cytomegalovirus-encoded interleukin-10. J Virol. 2002;76:1285-92.

25. Springer KL, Weinberg A. Cytomegalovirus infection in the era of HAART: fewer reactivations and more immunity. J Antimicrob Chemother. 2004;54:582-6.

26. Steininger C, Puchhammer-Stockl E, Popow-Kraupp T. Cytomegalovirus disease in the era of highly active antiretroviral therapy (HAART). J Clin Virol. 2006;37:1-9.

27. Tarragó D, Quereda C, Tenório A. Different cytomegalovirus glycoprotein B genotype distribution in serum and cerebrospinal fluid specimens determined by a novel multiplex nested PCR. J Clin Microbiol. 2003;41:2872-7.

28. Torok-Storb B, Boeckh M, Hoy C, Leisenring W, Myerson D, Gooley T. Association of specific cytomegalovirus genotypes with death from myelosuppression after marrow transplantation. Blood 1997;90:2097-102.

29. Yamamoto AY, Figueiredo LTM, Mussi-Pinhata MM. Infecção congênita por citomegalovirus: muito freqüente, mas pouco diagnosticada. J Pedriatr (Rio J). 1999;75:126-30.

Received: 18 June 2010

Accepted: 28 January 2011 